\title{
Ecophysiological properties of a cluster root- forming plant, Helicia cochinchinensis (Proteaceae) grown on Miyajima Island, Japan
}

Jun Wasaki ( $\boldsymbol{\sigma}$ junw@hiroshima-u.ac.jp )

Hiroshima University https://orcid.org/0000-0002-8344-607X

\section{Tadashi Okamura}

Hiroshima University

\section{Taiki Yamauchi}

Hiroshima University

\section{Hayato Maruyama}

Hiroshima University

\section{Shinji Uchida}

Hiroshima University

\section{Seiji Mukai}

Hiroshima University

Hiromi Tsubota

Hiroshima University

\section{Research Article}

Keywords: Helicia cochinchinensis, Phosphorus, Cluster roots, Proteaceae, P-remobilization efficiency

Posted Date: January 12th, 2022

DOI: https://doi.org/10.21203/rs.3.rs-1219032/v1

License: (c) (i) This work is licensed under a Creative Commons Attribution 4.0 International License. Read Full License 


\section{Abstract}

Aims The family Proteaceae is one of the dominant families in nutrient-impoverished habitats in the Southern hemisphere, and less common in the Northern hemisphere. Helicia cochinchinensis Lour. is the only Proteaceae species in Japan. This study aimed to unveil the ecophysiological properties of $H$. cochinchinensis grown on Miyajima Island, Hiroshima, Japan.

Methods Phosphorus $(\mathrm{P})$ status and dynamics of soils in $\mathrm{H}$. cochinchinensis habitats were measured. Plant $\mathrm{P}$ and nitrogen $(\mathrm{N})$ concentrations of leaves were measured after digestion. Roots and rhizosheath soil were collected to assess root morphology and root exudates.

Results Available $\mathrm{P}$ (Olsen-P) in soils in habitats of $H$. cochinchinensis was $0.46-3.7 \mathrm{mg} \mathrm{P} \mathrm{kg}^{-1}$ soil. Citrate was the major carboxylate in root exudates and its concentration increased during cluster-root formation. Acid phosphatase activity was greater at the surface of cluster roots that on the surface of other roots and bulk soil, especially for mature cluster roots. Sparingly soluble organic P concentrations decreased in the rhizosheath soil of mature cluster roots. The P concentrations of $H$. cochinchinensis leaves were relatively low; $0.34-0.69 \mathrm{mg} \mathrm{P} \mathrm{g}^{-1} \mathrm{DW}$ and $0.15-0.29 \mathrm{mg} \mathrm{P} \mathrm{g}^{-1} \mathrm{DW}$ in mature and senesced leaves, respectively. The $\mathrm{P}$ demand of $H$. cochinchinensis was less than that of nearby trees, showing greater P-remobilization efficiency.

Conclusions Phosphorus mobilization from unavailable $\mathrm{P}$ by cluster roots supported $\mathrm{P}$ uptake by $\mathrm{H}$. cochinchinensis, and $\mathrm{P}$ remobilization from senescing leaves contributed to sustain growth under $\mathrm{P}$ deficient conditions.

\section{Introduction}

The Proteaceae family comprises woody dicots that are distributed mainly in Australia and South Africa, which were part of Gondwana (Lambers et al. 2012a). Southwestern Australian native Proteaceae such as species in the genera Banksia, Grevillea, and Hakea are adapted to extremely nutrient-impoverishment soils that are especially low in phosphorus (P) (Lambers et al. 2011). The formation of a bottle-brush like root architecture, so-called 'cluster roots', is a strategy to adapt to P-deficiency (Neumann and Martinoia 2002). Cluster roots consist of very dense rootlets that are several millimeters long, produce a high density of root hairs on every rootlet, and release carboxylates in an exudative burst (Shane and Lambers 2005). Consequently, cluster roots can mobilize and take up $P$ from the rhizosphere. Both morphological and physiological alterations in the cluster roots are important for $\mathrm{P}$ uptake. Exudative bursts such as of carboxylates and phosphatases are strategies to mobilize unavailable P, such as sparingly soluble inorganic $P$ and organic $P$, in soils (Neumann and Martinoia 2002; Wasaki et al. 2003).

Phosphorus remobilization from senescing leaves is a well-known strategy for growth under P-deficient conditions. Some Proteaceae plants remobilize P from senescing leaves highly efficiently (Denton et al. 2007). Although global average values of the P-remobilizing efficiency (PRE) are about $50 \%$ (Lambers 
and Oliveira 2019), Banksia and Hakea species show a much greater PRE: greater than $80 \%$ (Denton et al. 2007; de Campos et al. 2013).

Replacement of phospholipids with galactolipids and sulfolipids during leaf development has been found in three Banksia and three Hakea species as an efficient P utilization strategy (Lambers et al. 2012b). Furthermore, $\mathrm{P}$ re-use from rRNA in same leaves during development has been shown in three Banksia and three Hakea species (Sulpice et al. 2014). The authors suggested that these properties contribute to the extremely high photosynthetic phosphorus-use efficiency of Proteaceae species.

A Southern South American Proteaceae in the genus Embothrium, naturally growing in young soils with high content of total P but low $\mathrm{P}$ availability, shows higher leaf $\mathrm{P}$ concentration and lower Premobilization efficiency than southwestern Australian Proteaceae species (Hayes et al. 2021). It has been suggested that cluster roots of Embothrium play a major role in the uptake of nitrogen $(\mathrm{N})$ rather than P (Fajardo and Piper 2015; Piper et al. 2013). In Asia, about 90 species belonging to the genus Helicia are distributed in Japan, China, India, Sri Lanka, Southeast Asia, and Pacific Islands (Jiang et al. 2011), but we have very little knowledge on their nutritional ecology. Among the family Proteaceae, only Helicia cochinchinensis Lour. occurs in Japan (Morimura et al. 2006). Miyajima Island, a natural habitat of $H$. cochinchinensis, has generally nutrient-poor soils, especially low in $\mathrm{P}$, and we have found that $H$. cochinchinensis produces simple-type cluster roots (Yamauchi et al. 2015). Therefore, $H$. cochinchinensis might have some adaptive properties associated with growth in low-P soils similar to southwestern Australian and South African Proteaceae.

This study aimed to unveil the ecophysiological properties involved in soil P mobilization by their roots and the P-remobilization efficiency of Helicia cochinchinensis growing in a natural habitat on Miyajima Island, Japan.

\section{Materials And Methods}

\section{Study Sites and Sampling}

The sampling site of Helicia cochinchinensis was Miyajima Island (Fig. 1), which has a warm and wet climate $\left(34^{\circ} 17^{\prime} \mathrm{N}, 132^{\circ} 17^{\prime} \mathrm{E}, 20 \mathrm{~m}\right.$ above sea level, annual precipitation $1,644 \mathrm{~mm}$, annual average temperature $15.8^{\circ} \mathrm{C}$ ). Two planted sites in the Miyajima Natural Botanical Garden (sites A and B), which is near natural habitats on the island, and three natural habitats on Miyajima Island (sites C, D, and E) were selected as study sites. Bulk soils near $H$. cochinchinensis plants at sites A-E were sampled and air-dried for analyses. The rhizosheath soil of $H$. cochinchinensis was sampled: cluster roots were collected from mature trees and gently shaken to remove non-rhizosheath soils adhered to the roots. The roots containing rhizosheath soil were transferred to $50 \mathrm{~mL}$ polypropylene tubes and shaken thoroughly. The roots were then removed from tubes and washed well with deionized water and used immediately for physiological analyses. Some roots were stored for DNA barcoding at $-20^{\circ} \mathrm{C}$ until analysis. The rhizosheath soil was also air-dried. 
Mature leaves of $H$. cochinchinensis and nearby trees were collected for elemental analysis. Senescing and dead leaves were also sampled from parts of trees. Fully expanded, yellowing, defoliated leaves were defined, respectively, as mature, senescing, and dead leaves. Leaves used for element analyses were oven-dried for three days at $70^{\circ} \mathrm{C}$.

\section{Soil Analysis}

All soil samples were sieved with a 2-mm sieve to remove large particles and roots. The samples were later used for analysis. Soil pH was determined in a water suspension (soil water ratio of 1:2.5) after shaking for one hour.

Total P of soils was determined using the vanadomolybdate blue method (Murphy and Riley 1962) after digestion of the sample with $\mathrm{H}_{2} \mathrm{SO}_{4}-\mathrm{H}_{2} \mathrm{O}_{2}$. Available $\mathrm{P}$ (Olsen $\mathrm{P}$ ) in the soil was analyzed according to Olsen et al. (1954). Phosphorus fractionation was conducted according to Hedley et al. (1982) with one modification in that a process to analyze soluble $\mathrm{P}$ was omitted, because Olsen-P already indicated a similar fraction.

\section{Sand Culture of $\mathrm{H}$. cochinchinensis}

Helicia cochinchinensis seedlings were collected on Miyajima Island and transferred to a cylindrical pot (190 $\mathrm{mm}$ in height and $160 \mathrm{~mm}$ in diameter) containing washed river sand. They were cultivated in a greenhouse through one year with continuous supply of a nutrient solution without P every seven days. Well-washed plants were used as -P individuals for observation of root morphology, collection of root exudates, and activity staining of acid phosphatase. After collection of root exudates, all plants were transferred to nutrient solution containing $P(320 \mu \mathrm{M})$ and cultured in a greenhouse. After six days of $P$ supply, all plants were used as $+P$ individuals for collection of root exudates and activity measurements of acid phosphatase.

\section{Analysis of Cluster Roots}

For the measurements of carboxylate exudation, exudates of whole roots of sand-cultured plants were collected by soaking in $200 \mathrm{~mL}$ of distilled water for $3 \mathrm{~h}$. Citrate and malate concentrations in root exudates were analyzed using an enzymatic method (F-kit, Roche, Basel, Switzerland). Numbers of cluster roots were counted for all analyzed plants.

Secreted and root-surface acid phosphatase activities of cluster roots were analyzed as below. The fresh roots were excised and soaked in distilled water for $1 \mathrm{~h}$ to remove leakage from root sections. The roots were transferred to new tubes containing $50 \mathrm{~mL}$ of distilled water for $3 \mathrm{~h}$ to collect root exudates. An aliquot $(0.5 \mathrm{~mL})$ of root exudates was added to $1.5 \mathrm{~mL}$ of $0.2 \mathrm{M}$ acetate-NaOH buffer ( $\mathrm{pH} 5.5)$, and 0.5 $\mathrm{mL}$ of substrate solution (10 mM p-nitrophenyl phosphate) was subsequently added. After incubation at $30^{\circ} \mathrm{C}$ for $30 \mathrm{~min}$, the reaction was stopped by adding $2.5 \mathrm{~mL}$ of $0.2 \mathrm{M} \mathrm{NaOH}$. To analyze total activity of acid phosphatase, the roots were immersed in a solution contained $30 \mathrm{~mL}$ of acetate-NaOH buffer, $10 \mathrm{~mL}$ of distilled water, and $10 \mathrm{~mL}$ of substrate solution at $30^{\circ} \mathrm{C}$ for $30 \mathrm{~min}$. The reaction was stopped after removal of the root system from the solution by adding $50 \mathrm{~mL}$ of $0.2 \mathrm{M} \mathrm{NaOH}$. Acid phosphatase 
activities were measured by spectrophotometry at $420 \mathrm{~nm}$ as increase of the $p$-nitrophenol concentration. Acid phosphatase activities on the root-surface were calculated by subtraction of secreted phosphatase activity from total activity.

Activity staining of phosphatase was conducted using 5-bromo-4-chloro-3-indolyl phosphate (BCIP) as a substrate. Washed cluster roots were soaked for 30-180 min in a staining solution containing $50 \mathrm{mM}$ sodium acetate ( $\mathrm{pH}$ 5.3), $10 \mathrm{mM} \mathrm{MgCl}_{2}$, and $0.1 \mathrm{mg} \mathrm{mL}^{-1} \mathrm{BCIP}$. Blue-stained samples were observed using a stereoscopic microscope.

\section{P Fractionation of the Soil}

To collect cluster roots exhibiting rapid exudation ability, the decrease of $\mathrm{pH}$ was used as the index. The $\mathrm{pH}$ alteration by root exudates was visualized using a $\mathrm{pH}$ indicator according to Shane et al. (2006). Briefly, roots collected in the field were directly placed on a $0.75 \%(\mathrm{w} / \mathrm{w})$ agar gel containing $0.008 \%(\mathrm{w} / \mathrm{v})$ of bromocresol purple as $\mathrm{pH}$ indicator.

For determination of soil P pools, sequential fractionation was conducted using the method described by Hedley et al. (1982) with minor modification. Briefly, $0.5 \mathrm{~g}$ of soil was weighed and extracted sequentially by shaking for $16 \mathrm{~h}$ with solutions as below. First, $30 \mathrm{~mL}$ of $0.5 \mathrm{M} \mathrm{NaHCO}_{3}$ was used after adjustment to $\mathrm{pH}$ 8.5. A second and third extraction used $30 \mathrm{~mL} 0.1 \mathrm{M} \mathrm{NaOH}(\mathrm{NaOH}-\mathrm{P})$ and $20 \mathrm{~mL} 1 \mathrm{M} \mathrm{HCl}$, respectively. Inorganic $\mathrm{P}(\mathrm{Pi})$ extracted by $\mathrm{NaHCO}_{3}$ and $\mathrm{NaOH}$ was measured as $\mathrm{NaHCO}_{3}-\mathrm{Pi}$ and $\mathrm{NaOH}-$ $\mathrm{Pi}$, respectively. Total $\mathrm{P}$ extracted by $\mathrm{NaHCO}_{3}, \mathrm{NaOH}$ and $\mathrm{HCl}$ was measured after digestion by autoclaving in $1.8 \mathrm{M} \mathrm{H}_{2} \mathrm{SO}_{4}$ with $\left(\mathrm{NH}_{4}\right)_{2} \mathrm{~S}_{2} \mathrm{O}_{8}$. Organic $\mathrm{P}(\mathrm{Po})$ in these fractions was calculated by subtraction the Pi from total P. Total $\mathrm{P}$ was determined by the vanadomolybdate blue method, after digestion.

\section{Elemental Analyses}

Dried leaves were ground using a mortar and pestle. A sample of approximately $50 \mathrm{mg}$ was digested using $\mathrm{H}_{2} \mathrm{SO}_{4}-\mathrm{H}_{2} \mathrm{O}_{2}$. Digested samples were used for analysis of total $\mathrm{P}$ and $\mathrm{N}$ concentrations, respectively, using the molybdate blue method and the indophenol method (Bolleter et al. 1961). The P-remobilization efficiency (PRE) was calculated as the difference between mature and senesced leaf $P$ concentrations divided by the mature leaf $P$ concentration (Killingbeck 1996).

\section{Statistical Analyses}

All cultivations were replicated more than three times. Student's t-test and Tukey's test were used with SPSS version 16J (SPSS Inc., Chicago, IL, USA). Significance was accepted at $P<0.01$ or $P<0.05$.

\section{Results}

\section{Helicia cochinchinensis habitat and the soil P status}


Mature H. cochinchinensis plants were about $20 \mathrm{~m}$ in height in Miyajima (Fig. 2A), flowering in early August (Fig. 2B). The shape of the seeds is elliptical with $1 \mathrm{~cm}$ in length of the longest dimension (Fig. 2C). The morphology of typical 'simple type' cluster roots (Fig. 2D, E, F) was found like in the genus Hakea (Shane and Lambers 2005). Cluster roots of $H$. cochinchinensis were found mainly within $10 \mathrm{~cm}$ from the soil surface. All individuals formed cluster roots, regardless of the differences of cultivation. Their cluster roots tightly bound soil particles and organic matter. The widths and lengths of clusters reached more than $1 \mathrm{~cm}$ and $3 \mathrm{~cm}$, respectively (Fig. 2E, F). The cluster roots were able to find from naturally grown $H$. cochinchinensis in all seasons.

We measured total and Olsen $\mathrm{P}$ concentrations of bulk soil sampled at five sites in $\mathrm{H}$. cochinchinensis habitats (Table 1). Total and Olsen P in soils in H. cochinchinensis habitats were, respectively, 135-329 and $0.46-3.7 \mathrm{mg} \mathrm{P} \mathrm{kg}^{-1}$ soil. Both values were highest at $H$. cochinchinensis-planted site $\mathrm{A}$, although these were less than one-tenth of the values in cropland close to Miyajima Island. The total P concentration in Miyajima was several times higher than the value in southwestern Australia, where Proteaceae plants are predominant. However, the level of Olsen-P in Miyajima was equivalent to or slightly higher than that in southwestern Australia, suggesting that Miyajima is extremely poor in available P. Soil pH was 5.3 or similar at all analyzed sites.

Table 1

Phosphorus status of soils in Helicia cochinchinensis habitats

\begin{tabular}{|llllll|}
\hline & Site A & Site B & Site C & Site D & Site E \\
\hline Total P $\left(\mathrm{mg} \mathrm{P} \mathrm{kg}^{-1}\right)$ & 329 & 271 & 201 & 186 & 135 \\
\hline Olsen-P $\left(\mathrm{mg} \mathrm{P} \mathrm{kg}^{-1}\right)$ & 2.8 & 2.1 & 0.46 & 0.46 & 0.20 \\
\hline
\end{tabular}

\section{Properties of $\mathrm{H}$. cochinchinensis cluster roots}

Citrate and malate exudation rates were analyzed using sand-cultured $H$. cochinchinensis plants (Table 2). Both citrate and malate exudation in -P plants were significantly greater than those in $+P$ plants, suggesting that these carboxylate exudations were induced by P-starved conditions in $\mathrm{H}$. cochinchinensis. The number of cluster roots per plant was positively correlated with both citrate and malate exudation rates (Fig. 4), indicating the contribution of cluster roots to carboxylate exudation. 
Table 2

Phosphorus (P)-mobilizing abilities of Helicia cochinchinensis rhizosheaths; statistical analysis for significant correlation is demonstrated with Student's t-test $(P<0.05)$

\begin{tabular}{|c|c|c|c|c|}
\hline \multirow[t]{2}{*}{ Treatment } & \multicolumn{2}{|c|}{$\begin{array}{l}\text { Organic acid exudation ( } \mathrm{nmol} \mathrm{g} \mathrm{g}^{-1} \mathrm{DW} \\
\mathrm{h}^{-1} \text { ) }\end{array}$} & \multicolumn{2}{|c|}{ Acid phosphatase $\left(\mu \mathrm{mol} \mathrm{g}{ }^{-1} \mathrm{DW} \mathrm{h}^{-1}\right)$} \\
\hline & Citrate & Malate & Root Surface & Secreted \\
\hline$+P$ & $36 \pm 16 a$ & $11 \pm 3.7 \quad a$ & $551 \pm 169$ a & $\begin{array}{l}2.2 \pm 0.7 \\
a\end{array}$ \\
\hline$-P$ & $97 \pm 23 b$ & $33 \pm 9.0 \quad b$ & $1242 \pm 264 b$ & $\begin{array}{l}49 \pm 6.1 \\
b\end{array}$ \\
\hline
\end{tabular}

Acid phosphatase activities were measured in different compartments. The results show that all activities were significantly higher in -P plants (Table 2). Interestingly, the activity of root-surface phosphatase was higher than that of root-secreted phosphatase. Activity staining of phosphatase was conducted using BCIP as a substrate. Activities were detected at the mature cluster root stage (Fig. 4AB). High intensity of blue-stained phosphatase was also found in the zone with high-density root hairs (Fig. 4C). The pH change around cluster roots of $H$. cochinchinensis grown in soil was also visualized (Fig. 4D). The pH reduction was stronger in the rhizosheath of mature cluster roots than that of senesced cluster roots. The strong $\mathrm{pH}$ reduction was the result of faster exudation of carboxylates, because proton release is concomitant with carboxylate release (Neumann and Martinoia 2002; Tomasi et al. 2009; Yan et al. 2002).

To investigate the effects of root exudates from cluster roots on the P dynamics of actual rhizosheath soils, sequential fractionation analysis of $\mathrm{P}$ was conducted for the bulk soil and the rhizosheath soils of cluster roots, which showed strong $\mathrm{pH}$ reductions. Total $\mathrm{P}$ concentration of the rhizosheath soil was mostly half of that of bulk soil, and concentrations of all fractions were lower in the rhizosheath soils (Fig. 5). Surprisingly, a reduction of the $\mathrm{NaOH}-\mathrm{Po}$ fraction in rhizosheath soil was common. This suggests that insoluble organic $\mathrm{P}$ was the major form of $\mathrm{P}$ mobilized by the cluster roots.

\section{Nutrient status of $\mathrm{H}$. cochinchinensis and nearby trees in Miyajima Island}

Phosphorus concentrations of mature and old leaves of $H$. cochinchinensis trees at five sites were analyzed (Table 3). Both mature and old leaves exhibited low values: $0.344-0.595 \mathrm{mg} \mathrm{g}^{-1}$ DW and $0.147-$ $0.282 \mathrm{mg} \mathrm{g}^{-1} \mathrm{DW}$, respectively. Phosphorus-remobilization efficiency (PRE) of $H$. cochinchinensis was greater than $50 \%$ in all individuals (Table 3 ), markedly higher than that of other nearby trees $(45.8 \%$ in Camellia japonica, 30.2\% in Diospyros morrisiana, and 7.9\% in Morella rubra), except for Michelia compressa (67.6\%). Thus suggests that $H$. cochinchinensis had a high capacity to remobilize $P$ from senescing leaves. 
Table 3

Phosphorus (P) concentration and P-remobilizing efficiency (PRE) of Helicia cochinchinensis leaves (mg $\left.\mathrm{P} \mathrm{g}^{-1} \mathrm{DW}\right)$

\begin{tabular}{|llllll|}
\hline & Site A & Site B & Site C & Site D & Site E \\
\hline $\begin{array}{l}\text { Mature } \\
\text { Leaves }\end{array}$ & $0.595 \pm 0.079$ & $0.591 \pm 0.072$ & $0.344 \pm 0.032$ & $0.399 \pm 0.036$ & 0.475 \\
& & & & \pm \\
Old & $0.282 \pm 0.030$ & $0.259 \pm 0.005$ & $0.147 \pm 0.009$ & $0.184 \pm 0.015$ & 0.192 \\
Leaves & & & & & \pm \\
\hline PRE (\%) & 52.6 & 56.1 & 57.3 & 53.9 & 59.6 \\
\hline
\end{tabular}

The $P$ concentrations of mature leaves of native trees were compared at the family level (Fig. 6). The trees frequently found in Miyajima Island were selected as follows: Anacardiaceae (Toxicodendron trichocarpum and Rhus javanica; $n=3$ ), Apocynaceae (Anodendron affine, Nerium oleander, and Trachelospermum asiaticum; $n=3$ ), Daphniphyllaceae (Daphniphyllum teijsmannii; $n=5$ ), Ebenaceae (Diospyros morrisiana; $n=3$ ), Ericaceae (Lyonia ovalifolia, Pieris japonica, Rhododendron kaempferi, $R$. reticulatum, and Vaccinium bracteatum; $n=5$ ), Fagaceae (Lithocarpus glabra, Quercus glauca, and $Q$. phillyraeoides; $n=5$ ), Lauraceae (Cinnamomum camphora, C. tenuifolium, Neolistea aciculata, $N$. sericea, and Litsea coreana; $n=6$ ), Magnoliaceae (Michelia compressa; $n=4$ ), Myricaceae (Morella rubra; $n=3$ ), Proteaceae (H. cochinchinensis; $n=20$ ), Rosaceae (Cerasus jamasakura, Photinia glabra, and Rubus sieboldii; $n=4$ ), Symplocaceae (Symplocos prunifolia and S. theophrastaefolia; $n=4$ ), and Theaceae (Camellia japonica; $n=3$ ). The P concentration was highest in Anacardiaceae and lowest in Myricaceae. The Proteaceae, which comprised only $\mathrm{H}$. cochinchinensis, exhibited very low values: $0.69 \mathrm{mg} \mathrm{P} \mathrm{g}^{-1} \mathrm{DW}$ was the highest value and $0.45 \mathrm{mg} \mathrm{P} \mathrm{g}^{-1} \mathrm{DW}$ was the median. This value was fourth from the lowest among analyzed plants.

The $\mathrm{P}$ and $\mathrm{N}$ concentrations of mature, senesced, and dead leaves were compared among $\mathrm{H}$. cochinchinensis, Camellia japonica, and Michelia compressa which showed higher PRE. Both concentrations were low in senesced and dead leaves and high in mature leaves in all plant species (Fig. 7). A linear correlation was found between $N$ and $P$ concentrations in all plants. The slopes for Camellia and Michelia were similar. Helicia cochinchinensis showed a lower slope than other species did (Fig. 7), suggesting that the relative demand of $\mathrm{P}$ to $\mathrm{N}$ in $\mathrm{H}$. cochinchinensis was less than that in other species, even in those planted at the same places.

\section{Discussion}

\section{Phosphorus mobilization in the rhizosheath of cluster roots}

Helicia cochinchinensis formed simple cluster roots (Fig. 2), as do most Proteaceae (Shane and Lambers 2005). This morphology has benefits for $P$ uptake via increasing of root surface areas and massive 
release of root exudates. Physiological alteration in the cluster roots of $H$. cochinchinensis was similar to that of other Proteaceae from Australia, South Africa and South America (Shane and Lambers 2005).

Cluster roots caused a strong decrease of $\mathrm{pH}$ in the rhizosheath (Figs. 4D, 5) and showed massive carboxylate exudation (Fig. 3). Earlier reports have described that the $\mathrm{pH}$ decrease and carboxylate exudation contribute to P mobilization in the rhizosheath (Neumann and Martinoia 2002; Weisskopf et al. 2006). The rate of citrate exudation was second only to that of white lupin (ca. $200 \mathrm{nmol} \mathrm{g}^{-1} \mathrm{DW} \mathrm{h}^{-1}$; Wang et al. 2007) and was similar to other Proteaceae (ca. $0.8 \mathrm{nmol} \mathrm{g}^{-1} \mathrm{FW} \mathrm{s}^{-1}$, Embothrium coccineum; Delgado et al. 2014) among previous studies. A strong exudation of carboxylate was consistent with an "exudative burst" found in cluster-root forming plant species (Skene 2003). Roelofs et al. (2001) reported a stronger carboxylate exudation from Proteaceae species in southwestern Australia than in white lupin. We speculate that $H$. cochinchinensis plants exhibit carboxylate exudation abilities from cluster roots as in other Proteaceae.

Phosphatases cleave phosphate ester bonds of a broad range of organic $\mathrm{P}$ compounds in soils, and can contribute to the supply of inorganic P. Both secreted and root surface-bound phosphatases mobilize organic $P$ in the rhizosheath (Wasaki et al. 2003). In H. cochinchinensis, the phosphatase activities on the root surface were predominant rather than the root secreted phosphatases (Table 2). This is inconsistent with previous studies on hydroponically-cultured crop plants, in which secreted phosphatases showed higher activities than cell wall-bound phosphatases (e.g., Tadano and Sakai 1991). The reason may be the characteristics of the cluster roots. The cluster roots develop dense root hairs on their rootlets to increase the root surface area. Thus the rhizosheath of cluster roots has a larger volume than other roots of the same weight. The stronger activities on root surfaces seems reasonable for cluster root-forming plants, such as Proteaceae. Indeed, mature cluster roots and their root hair cells showed stronger activities of phosphatase by the activity staining of root-surface phosphatases (Fig. 4). The phosphatase activity of the entire root system of Embothrium coccineum was less than $150 \mu \mathrm{mol} \mathrm{g}^{-1} \mathrm{DW} \mathrm{h}^{-1}$ (Delgado et al. 2013), suggesting that $H$. cochinchinensis had markedly high activities (Table 2). Given the higher organic P content in the soil of $H$. cochinchinensis habitats in Miyajima (Fig. 5), it seems reasonable for the role to mobilize the organic $P$ in the rhizosheath soils.

Effects of P-mobilizing abilities in the rhizosheath of $H$. cochinchinensis on actual soils were estimated by a sequential fractionation. Surprisingly, more than half of total $P$ in bulk soil disappeared in the rhizosheath soils (Fig. 5), suggesting that P-mobilization abilities of the rhizosheath significantly contributed to $\mathrm{P}$ acquisition from 'unavailable' $\mathrm{P}$ in soil. $\mathrm{NaOH}-\mathrm{Po}$, which was a drastically decreased fraction in the rhizosheath soils, contained phytate-P, the most abundant organic $P$ in soils (Dissanayaka et al. 2015). Phytate-P is the most difficult to utilize for plants among organic $P$ compounds present in soil (Turner 2008). Our preliminary analysis suggested that the soil of $H$. cochinchinensis habitat contains phytate-P (data not shown), contrasting with none of phytate-P in an ancient soil of Xylomelum occidentale habitat (Zhoung et al. 2021). An ability to mobilize sparingly soluble phytate-P may be advantageous for growth of $H$. cochinchinensis, although further studies are required to show the dynamics of phytate-P in the rhizosheath. 


\section{Phosphorus remobilization from senescing leaves}

The critical level of $\mathrm{P}$ in crop plants to avoid $\mathrm{P}$ deficiency is $2 \mathrm{mg} \mathrm{P} \mathrm{g}^{-1}$ DW (Marschner 2012, Tadano and Sakai 1991). The P concentration of mature leaves of native trees in Miyajima was much lower (Fig. 6 , Table 3). The median of $\mathrm{P}$ concentration of $H$. cochinchinensis was fourth from the lowest among the plants investigated on Miyajima Island (Fig. 6), and mostly average for Proteaceae (Westoby and Falster 2021). This suggests that many plant species in Miyajima Island including $H$. cochinchinensis can tolerate low-P conditions and function at low leaf $\mathrm{P}$ concentrations.

Phosphorus remobilization of Proteaceae in southwestern Australia is extremely important for growth in soil containing very little $\mathrm{P}$ (Lambers et al. 2012b, 2015). The P-remobilization efficiency of $H$. cochinchinensis from senesced leaves was greater than $50 \%$ for all investigated trees (Table 3 ). Phosphorus remobilization of $\mathrm{H}$. cochinchinensis was greater than that of nearby trees of other families, although the PRE was lower than that of southwestern Australian species.

The Southern South American Proteaceae Embothrium coccineum naturally occurs in volcanic soils, which have a high total $\mathrm{P}$ concentration but low $\mathrm{P}$ availability due to strong $\mathrm{P}$ sorption. These plants show only $42 \%$ P-remobilization efficiency, although this value is higher than that of nearby trees (Fajardo and Piper 2015). The P-remobilization efficiency of $H$. cochinchinensis was markedly higher than that of Embothrium coccineum (de Campos et al. 2013). Higher PRE in Proteaceae than in other families commonly occurs in three different regions (Australia, Chile, and Japan). Mature leaves of wide range of Proteaceae showed low $P$ concentration (Hayes et al. 2021). These facts suggest that efficient $P$ use is important for $\mathrm{P}$ nutrition in Proteaceae.

P-N interactions suggest a relatively low $\mathrm{P}$ demand in $\mathrm{H}$. cochinchinensis. The slope of the correlation for H. cochinchinensis tended to be lower than those of the other two trees (Fig. 7), suggesting that $P$ demand of $\mathrm{H}$. cochinchinensis was less than that of nearby trees showing high $\mathrm{P}$ use efficiency. Wright et al. (2004) reported that mature leaf N:P ratios of southwestern Australian Proteaceae was 24.4, whereas those of tested species on Miyajima Island were lower. Nitrogen concentrations of senesced leaves were lower than those of mature leaves (Fig. 7). Mature leaf $\mathrm{N}$ concentrations were higher among Proteaceae (Westby and Falster 2021). Resorption of $\mathrm{N}$ from litter to green leaves was low in southwestern Australian Proteaceae plants (Lambers et al. 2012a). This suggests that both $\mathrm{P}$ and $\mathrm{N}$ are limiting nutrients for Miyajima trees, although $\mathrm{P}$ is the strongest limiting nutrient, as is the case for southwestern Australian species.

\section{Concluding Remarks}

Morphological and physiological properties of cluster roots of $H$. cochinchinensis on Miyajima Island support $\mathrm{P}$ uptake from poorly available $\mathrm{P}$ sources in the soil like those of other Proteaceae. Actually, $\mathrm{P}$ remobilization from senescing leaves and less $\mathrm{P}$ demand in leaves may sustain the growth of $H$. cochinchinensis under P-deficient conditions. The ecological and physiological importance of $H$. 
cochinchinensis can be assessed further by comparison between $\mathrm{H}$. cochinchinensis at Miyajima and other Proteaceae grown in climatically and geologically different places.

\section{Declarations}

\section{Acknowledgments}

This research was partly supported by the Ministry of Education, Culture, Sports, Science and Technology (MEXT), Japan through Grants-in-Aid (23688010, 23770089, 17H03783 and 17KK0156). We thank Prof. Hans Lambers for providing constructive comments on draft of this manuscript.

\section{References}

1. Bolleter WT, Bushman CJ, Tidwell PW (1961) Spectrophotometric determination of ammonia as indophenol. Anal Chem 33:692-594. https://doi.org/10.1021/ac60172a034

2. CBOL Plant Working Group (2009) A DNA barcode for land plants. Proc Natl Acad Sci USA 106:12794-12797. http://doi.org/10.1073/pnas.0905845106

3. de Campos M, Pearse SJ, Oliveira RS, Lambers H (2013) Down-regulation of net phosphorus-uptake capacity is inversely related to leaf phosphorus-resorption proficiency in four species from a phosphorus-impoverished environment. Ann Bot 111:445-454.

https://doi.org/10.1093/aob/mcs299

4. Delgado M, Zúñiga-Feest A, Alvear M, Borie F (2013) The effect of phosphorus on cluster-root formation and functioning of Embothrium coccineum (R. et J. Forst.). Plant Soil 373:765-773. https://doi.org/10.1007/s11104-013-1829-3

5. Delgado M, Zúñiga-Feest A, Borie F, Suriyagoda L, Lambers H (2014) Divergent functioning of Proteaceae species: the South American Embothrium coccineum displays a combination of adaptive traits to survive in high-phosphorus soils. Funct Ecol 28:1356-1366. https://doi.org/10.1111/13652435.12303

6. Denton MD, Veneklaas EJ, Freimoser FM, Lambers H (2007) Banksia species (Proteaceae) from severely phosphorus-impoverished soils exhibit extreme efficiency in the use and re-mobilization of phosphorus. Plant Cell Environ 30:1557-1565. https://doi.org/10.1111/j.1365-3040.2007.01733.x

7. Dinkelaker B, Hengeler C, Marschner H (1995) Distribution and function of proteoid roots and other root clusters. Bot Acta 108:183-200. https://doi.org/10.1111/j.1438-8677.1995.tb00850.x

8. Dinkelaker B, Römheld V, Marschner H (1989) Citric acid excretion and precipitation of calcium citrate in the rhizosphere of white lupin (Lupinus albus L.). Plant Cell Environ 12:285-292. https://doi.org/10.1111/j.1365-3040.1989.tb01942.x

9. Fajardo A, Piper FI (2015) High foliar nutrient concentrations and resorption efficiency in Embothrium coccineum (Proteaceae) in southern Chile. Am J Bot 102:208-216. https://doi.org/10.3732/ajb.1400533 
10. Hayes PE, Nge FJ, Cramer MD, Finnegan PM, Fu P, Hopper SD, Oliveira RO, Turner BL, Zemunik G, Zhong $\mathrm{H}$, Lambers $\mathrm{H}$ (2021) Traits related to efficient acquisition and use of phosphorus promote diversification in Proteaceae in old phosphorus-impoverished landscapes. Plant Soil 462:67-88. https://doi.org/10.1007/s11104-021-04886-0

11. Hedley MJ, Stewart JWB, Chauhan BS (1982) Changes in inorganic and organic soil phosphorus fractions induced by cultivation practices and by laboratory incubations. Soil Sci Soc Am J 46:970976. https://doi.org/10.2136/sssaj1982.03615995004600050017x

12. Jiang N, Lin X, Guan K-Y, Yu W-B (2011) Valid publication of the name Helicia falcata (Proteaceae). Nord J Bot 29:61-62. 10.1111/j.1756-1051.2010.00900.x

13. Killingbeck KT (1996) Nutrients in senesced leaves: keys to the search for potential resorption and resorption proficiency. Ecology 77:1716-1727. https://doi.org/10.2307/2265777

14. Lambers H, Oliveira RS (2019) Plant physiological ecology. 3rd edition. Springer, Cham

15. Lambers H, Finnegan PM, Laliberte E, Pearse SJ, Ryan MH, Shane MW, Veneklaas EJ (2011) Phosphorus nutrition of Proteaceae in severely phosphorus-impoverished soils: Are there lessons to be learned for future crops? Plant Physiol 156:1058-1066. https://doi.org/10.1104/pp.111.174318

16. Lambers H, Bishop JG, Hopper SD, Laliberté E, Zúñiga-Feest A (2012a) Phosphorus- mobilization ecosystem engineering: the roles of cluster roots and carboxylate exudation in young P-limited ecosystems. Ann Bot 110:329-348. https://doi.org/10.1093/aob/mcs130

17. Lambers H, Cawthray GR, Giavalisco P, Kuo J, Laliberte E, Pearse SJ, Scheible W-R, Stitt M, Teste F, Turner BL (2012b) Proteaceae from severely phosphorus-impoverished soils extensively replace phospholipids with galactolipids and sulfolipids during leaf development to achieve a high photosynthetic phosphorus-use-efficiency. New Phytol 196:1098-1108. https://doi.org/10.1111/j.1469-8137.2012.04285.x

18. Lambers H, Finnegan PM, Jost R, Plaxton WC, Shane MW, Stitt M (2015) Phosphorus nutrition in Proteaceae and beyond. Nat Plants 1:15109. https://doi.org/10.1038/nplants.2015.109

19. Marschner H (2012) Marschner's mineral nutrition of higher plants. Third Edition. Academic Press, London

20. Maruyama H, Yamamura T, Kaneko Y, Matsui H, Watanabe T, Shinano T, Osaki M, Wasaki J (2012) Effect of exogenous phosphatase and phytase activities on organic phosphate mobilization in soils with different phosphate adsorption capacities. Soil Sci Plant Nutr 58:41-51. https://doi.org/10.1080/00380768.2012.656298

21. Morimura K, Gatayama A, Tsukimata R, Matsunami K, Otsuka H, Hirata E, Shinzato T, Aramoto M, Takeda Y (2006) 5-O-glucosyldihydroflavones from the leaves of Helicia cochinchinensis. Phytochemistry 67:2681-2685. https://doi.org/10.1016/j.phytochem.2006.08.001

22. Murphy J, Riley JP (1962) A modified single solution method for the determination of phosphate in natural waters. Anal Chim Acta 27:31-36

23. Neumann G, Martinoia E (2002) Cluster roots - an underground adaptation for survival in extreme environments. Trends Plant Sci 7:162-167. https://doi.org/10.1016/S1360-1385(02)02241-0 
24. Olsen SR, Cole CV, Watanabe FS, Dean LA (1954) Estimation of available phosphorus in soils by extraction with sodium bicarbonate. USDA Circular No. 939, Washington DC

25. Piper Fl, Baeza G, Zúñiga-Feest A, Fajardo A (2013) Soil nitrogen, and not phosphorus, promotes cluster-root formation in a South American Proteaceae, Embothrium coccineum. Am J Bot 100:2328-2338. https://doi.org/10.3732/ajb.1300163

26. Roelofs RFR, Rengel Z, Cawthray GR, Dixon KW, Lambers H (2001) Exudation of carboxylates in Australian Proteaceae: chemical composition. Plant Cell Environ 24:891-903. https://doi.org/10.1046/j.1365-3040.2001.00741.x

27. Shane MW, Lambers H (2005) Cluster roots: a curiosity in context. Plant Soil 274:101-125. https://doi.org/10.1007/s11104-004-2725-7

28. Shane MW, Cawthray GR, Cramer MD, Kuo J, Lambers H (2006) Specialized 'dauciform' roots of Cyperaceae are structurally distinct, but functionally analogous with 'cluster' roots. Plant Cell Environ 29. https://doi.org/10.1111/j.1365-3040.2006.01574.x. :1989-1999

29. Skene KR (1998) Cluster roots: some ecological considerations. J Ecol 86:1060-1064. https://doi.org/10.1046/j.1365-2745.1998.00326.x

30. Sulpice R, Ishihara H, Schlereth A, Cawthray GR, Encke B, Giavalisco P, Ivakov A, Arrivault S, Jost R, Krohn N, Kuo J, Laliberté E, Pearse SJ, Raven JA, Scheible W-R, Teste F, Veneklaas EJ, Stitt M, Lambers $\mathrm{H}$ (2014) Low levels of ribosomal RNA partly account for the very high photosynthetic phosphorus-use efficiency of Proteaceae species. Plant Cell Environ 37:1276-1298. https://doi.org/10.1111/pce.12240

31. Tadano T, Sakai H (1991) Secretion of acid phosphatase by the roots of several crop species under phosphorus-deficient conditions. Soil Sci Plant Nutr 37:129-140. https://doi.org/10.1080/00380768.1991.10415018

32. Tomasi N, Kretzschmar T, Espen L, Weisskopf L, Fuglsang AT, Palmgren MG, Neumann G, Varanini Z, Pinton R, Martinoia E, Cesco S (2009) Plasma membrane $\mathrm{H}^{+}$-ATPase dependent citrate exudation from cluster roots of phosphate-deficient white lupin. Plant Cell Environ 32:465-475. https://doi.org/10.1111/j.1365-3040.2009.01938.x

33. Thompson JD, Higgins DG, Gibson TJ (1994) CLUSTAL W: improving the sensitivity of progressive multiple sequence alignment through sequence weighting, position-specific gap penalties and weight matrix choice. Nucleic Acids Res 22:4673-4680. https://doi.org/10.1093/nar/22.22.4673

34. Wang BL, Shen JB, Zhang WH, Zhang FS, Neumann G (2007) Citrate exudation from white lupin induced by phosphorus deficiency differs from that induced by aluminum. New Phytol 176:581-589. https://doi.org/10.1111/j.1469-8137.2007.02206.x

35. Wasaki J, Yamamura T, Shinano T, Osaki M (2003) Secreted acid phosphatase is expressed in cluster roots of lupin in response to phosphorus deficiency. Plant Soil 248:129-136. https://doi.org/10.1023/A:1022332320384

36. Wasaki J, Rothe A, Kania A, Neumann G, Römheld V, Shinano T, Osaki M, Kandeler E (2005) Root exudation, phosphorus acquisition, and microbial diversity in the rhizosphere of white lupine as 
affected by phosphorus supply and atmospheric carbon dioxide concentration. J Environ Qual 34:2157-2166. https://doi.org/10.2134/jeq2004.0423

37. Wasaki J, Kojima S, Maruyama H, Haase S, Osaki M, Kandeler E (2008) Localization of acid phosphatase activities in roots of white lupin plants grown under phosphorus-deficient conditions. Soil Sci Plant Nutr 54:95-102. https://doi.org/10.1111/j.1747-0765.2007.00207.x

38. Weisskopf L, Abou-Mansour E, Fromin N, Tomasi N, Santelia D, Edelkott I, Neumann G, Aragno M, Tabacchi R, Martinoia E (2006) White lupin has developed a complex strategy to limit microbial degradation of secreted citrate required for phosphate acquisition. Plant Cell Environ 29:919-927. https://doi.org/10.1111/j.1365-3040.2005.01473.x

39. Westby M, Falster DS (2021) The conservative low-phosphorus niche in Proteaceae. Plant Soil 462:89-93. https://doi.org/10.1007/s11104-021-04953-6

40. Wright IJ, Reich PB, Westoby M, Ackerly DD, Baruch Z, Bongers F, Cavender-Bares J, Chapin T, Cornelissen JHC, Diemer M, Flexas J, Garnier E, Groom PK, Gulias J, Hikosaka K, Lamont BB, Lee T, Lee W, Lusk C, Midgley JJ, Navas M-L, Niinemets Ü, Oleksyn J, Osada N, Poorter H, Poot P, Prior L, Pyankov VI, Roumet C, Thomas SC, Tjoelker MG, Veneklaas EJ, Villar R (2004) The worldwide leaf economics spectrum. Nature 428:821-827. https://doi.org/10.1038/nature02403

41. Yan F, Zhu Y, Müller C, Zörb C, Schubert S (2002) Adaptation of $\mathrm{H}^{+}$-pumping and plasma membrane $\mathrm{H}^{+}$ATPase activity in proteoid roots of white lupin under phosphate deficiency. Plant Physiol 129:50-63. https://doi.org/10.1104/pp.010869

42. Zhong H, Zhou J, Azmi A, Arruda AJ, Doolette AL, Smernik RJ, Lambers H (2021) Xylomelum occidentale (Proteaceae) accesses relatively mobile soil organic phosphorus without releasing carboxylates. J Ecol 109:246-259. https://doi.org/10.1111/1365-2745.13468

\section{Figures}

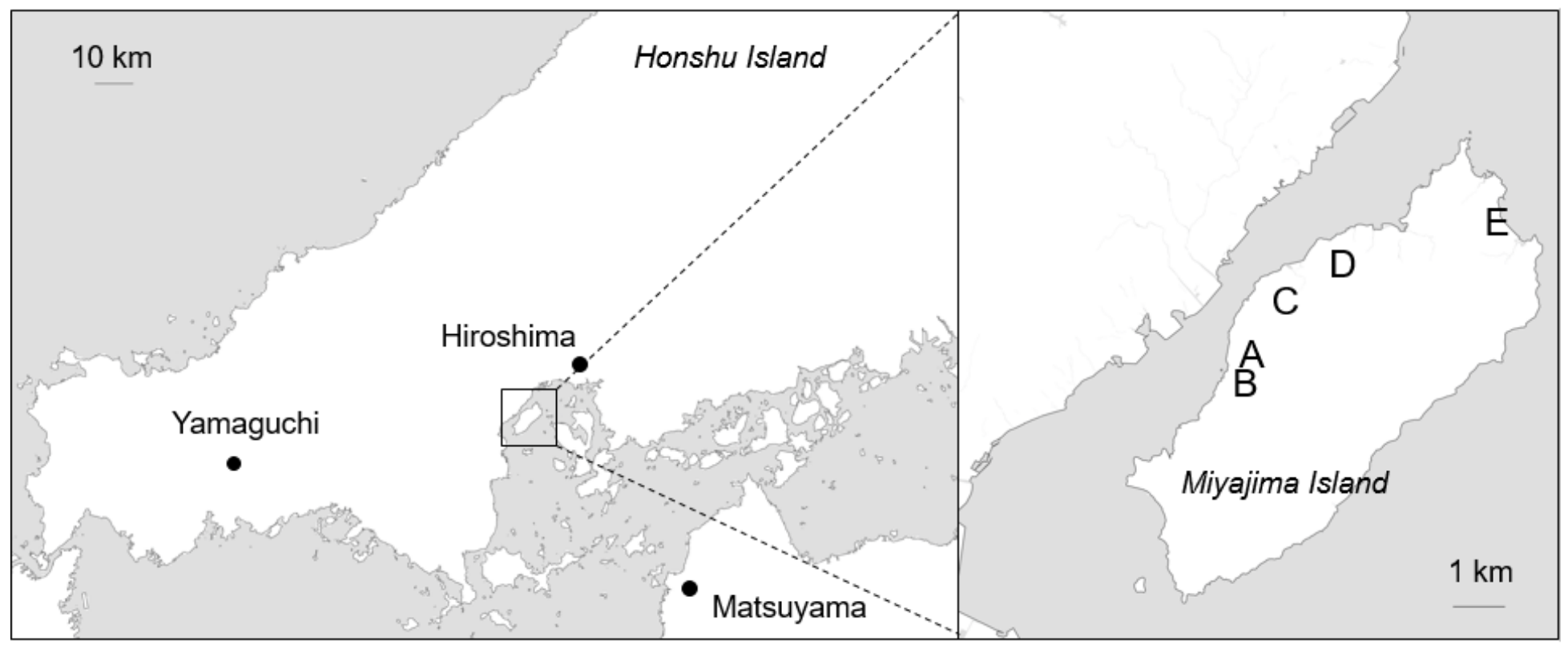


Figure 1

Study Sites. Left: part of western Japan including Miyajima Island. Right: close-up view of Miyajima Island, including study sites A-E. Maps were modified from the electronic data provided by Geographical Survey Institute, Japan.

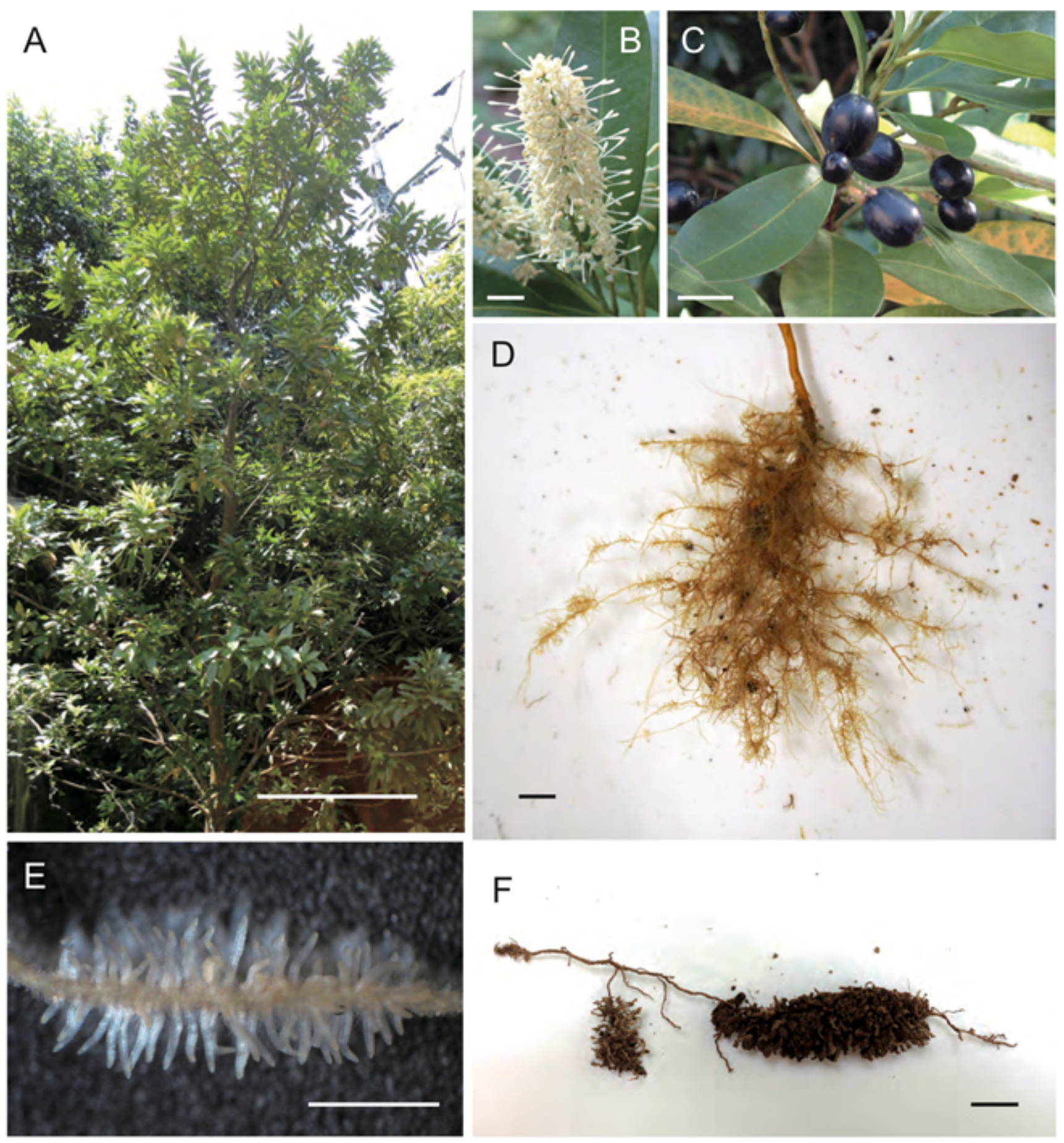

Figure 2

Helicia cochinchinensis plants. A, Tree growing on Miyajima Island; B, a flower, C, fruits; D, whole root system of hydroponically cultured plant; $E$, a cluster root of hydroponically-cultured plant; $F$, a cluster root 
of a tree growing naturally on Miyajima Island. Bars $=1 \mathrm{~m}(\mathrm{~A})$ or $1 \mathrm{~cm}(\mathrm{~B}-\mathrm{F})$.

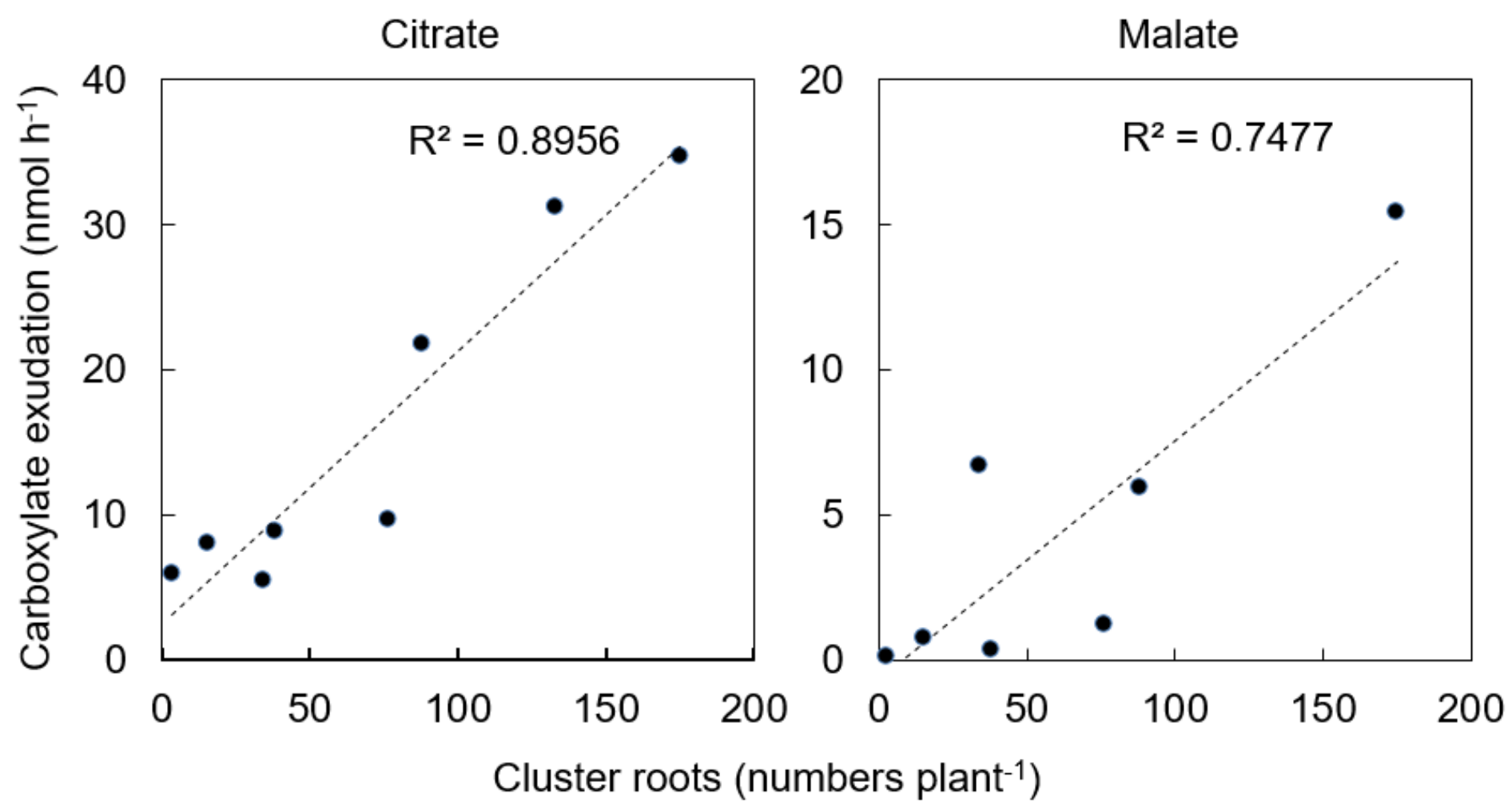

Figure 3

Relationships between cluster-root formation and carboxylate exudation. A, citrate exudation; B, malate exudation. 


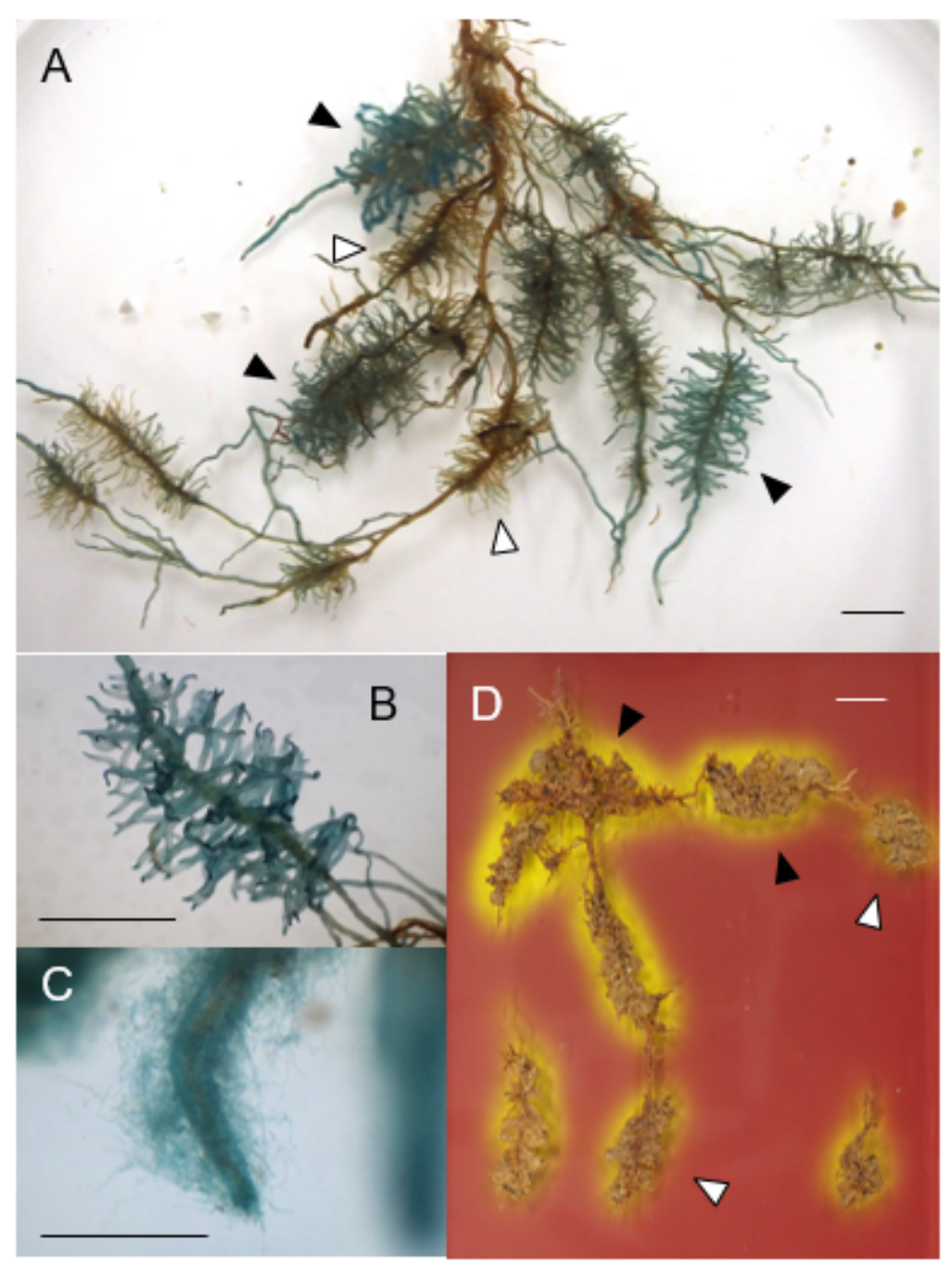

Figure 4

Distribution of acid phosphatase activities in cluster roots of Helicia cochinchinensis. A, A cluster root found on a tree growing on Miyajima Island; B, a rootlet; C, whole root system of a sand-cultured Helicia cochinchinensis. Bar $=1 \mathrm{~mm}(\mathrm{~A}-\mathrm{B})$ or $1 \mathrm{~cm}(\mathrm{C})$. 


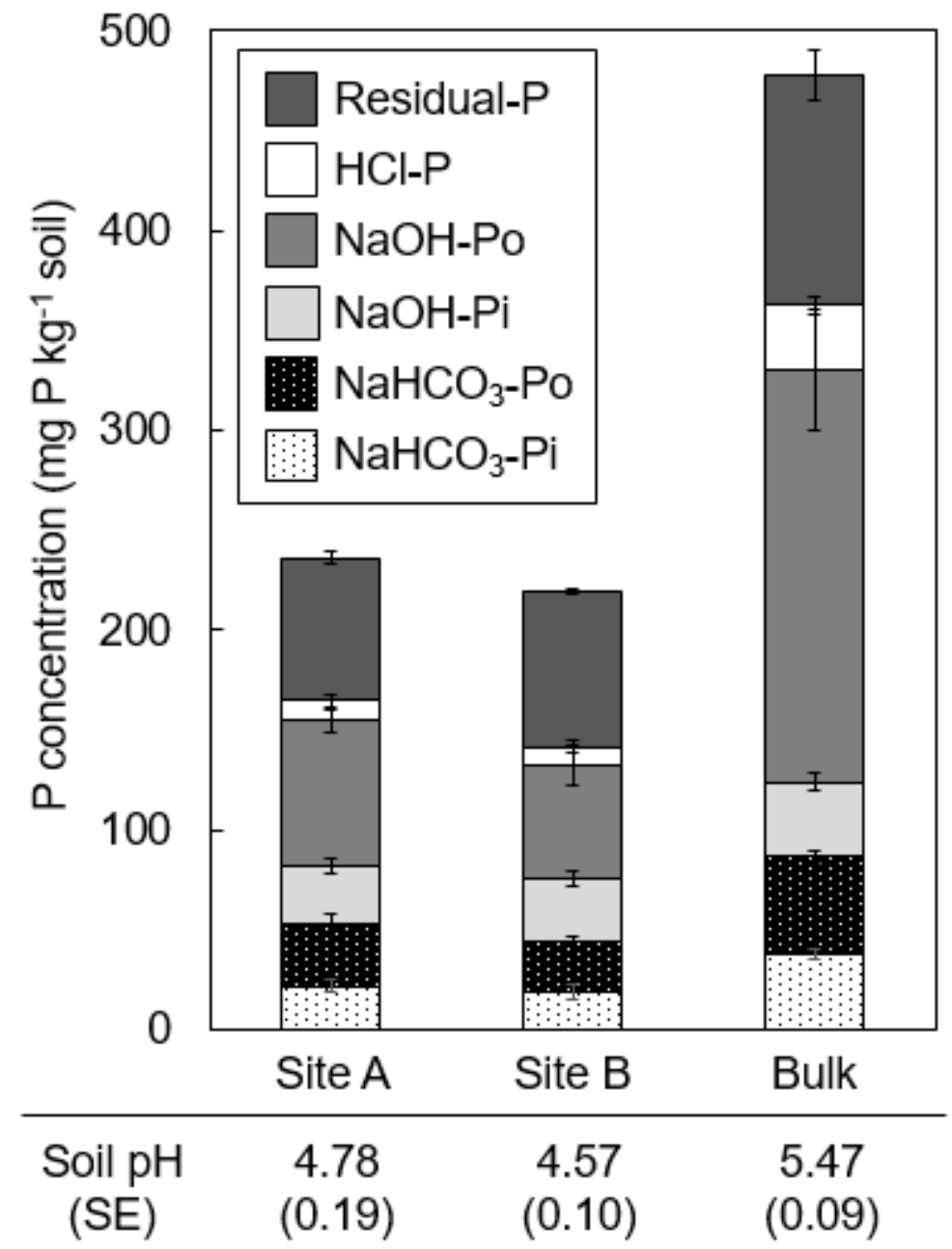

Figure 5

Phosphorus fractionation and pH of rhizosheath soils of cluster roots and bulk soils. 


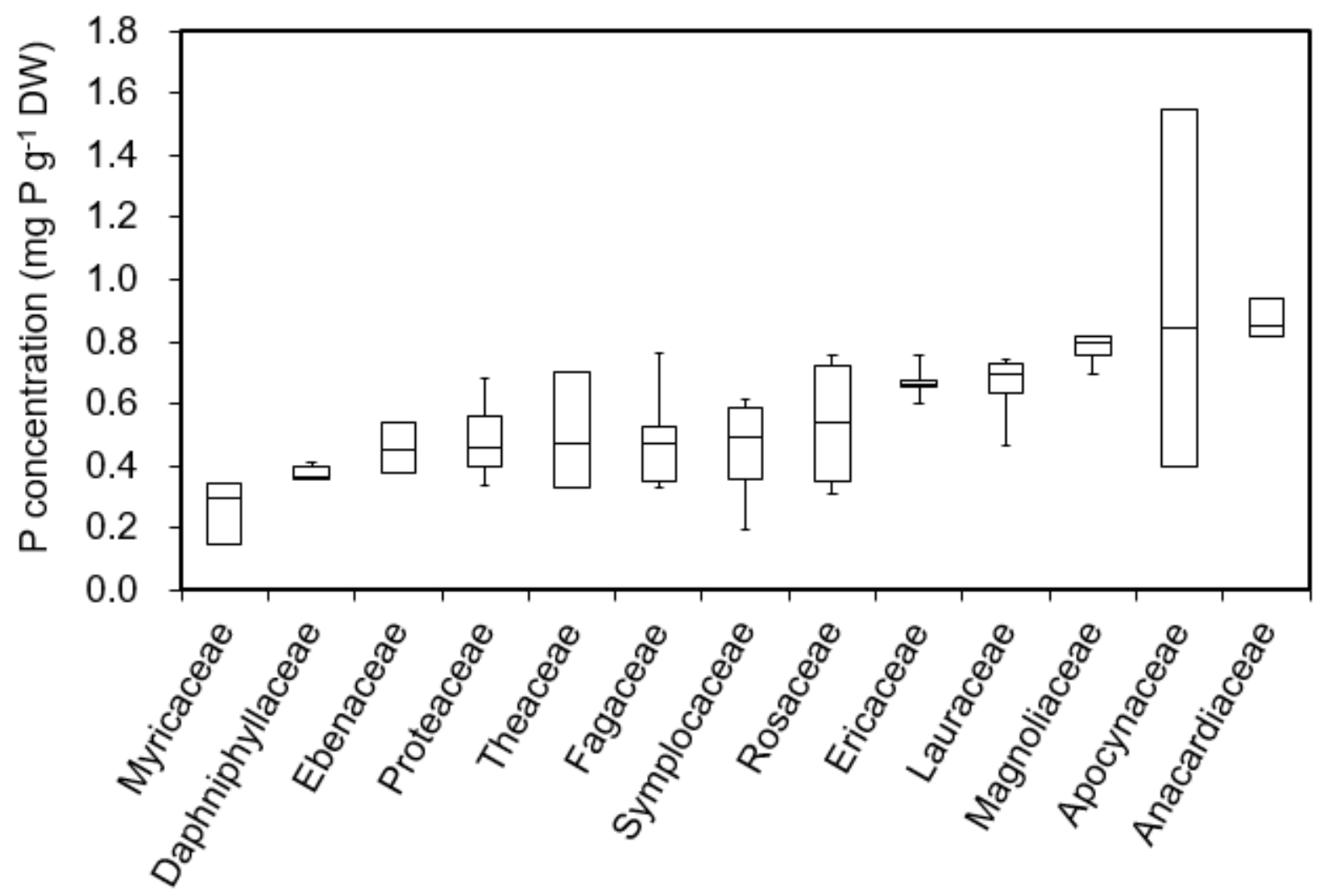

Figure 6

Phosphorus concentration of mature leaves of native trees on Miyajima Island.

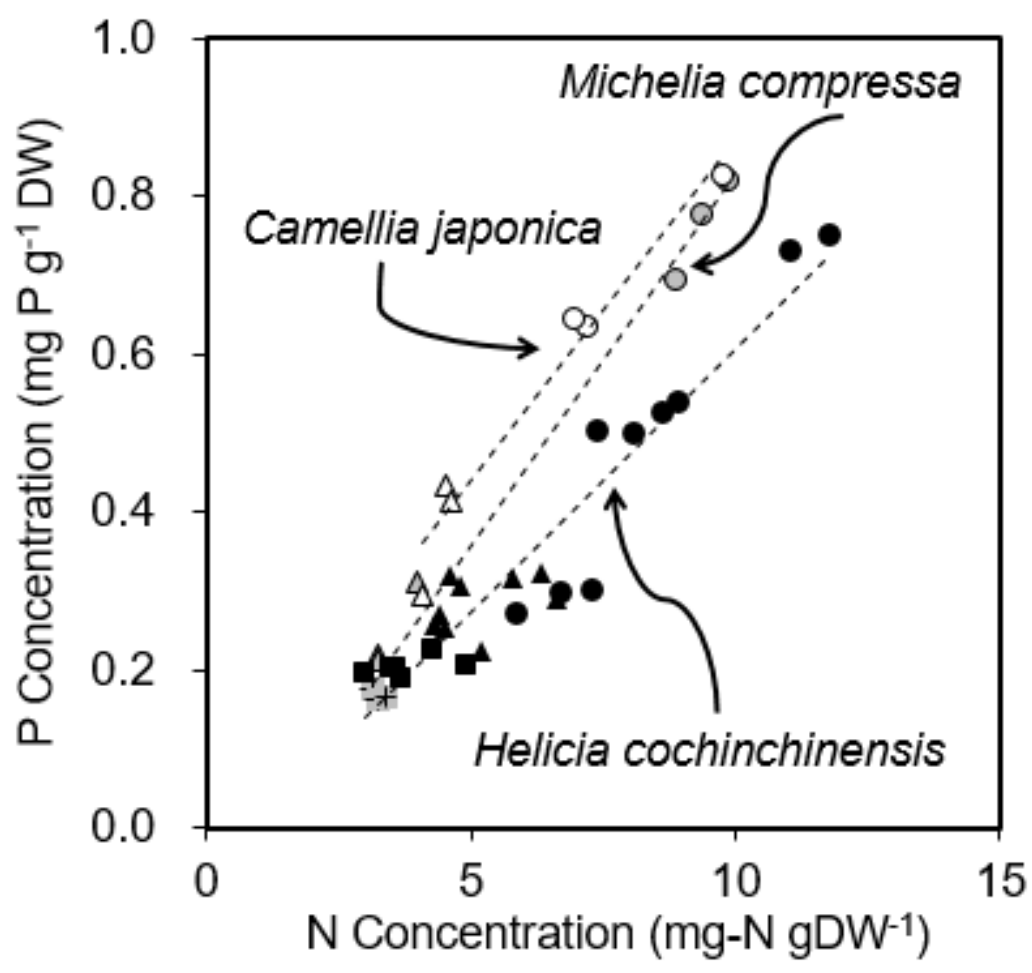


Figure 7

Interaction between nitrogen $(\mathrm{N})$ and phosphorus $(\mathrm{P})$ concentrations in leaves. Black, gray, and white symbols, respectively, denote Helicia cochinchinensis, Michelia compressa, and Camellia japonica. Circles, triangles, and squares, respectively, denote mature, senesced, and dead leaves. 